\title{
TAREKAT AND WORK ETHOS OF MUSLIM BUSINESSES (Study of Work Ethics Based on Sufism)
}

\author{
Ivan Rahmat Santoso \\ Universitas Negeri Gorontalo \\ ivanrahmatsantoso@gmail.com
}

\begin{abstract}
This paper examines the role of thetarekatasa spiritual means of getting closer to Allah SWT, and how to significantly influence the work ethic of entrepreneurs, based on Sufism values. The method used in this study is library research. It aims to constructively analyze the contributions and role of the teachings of the tarekat towards the work ethic of the business entrepreneurial behavior of its followers. This result showed that the tarekat, as a remembrance or recollection of God, purifies the soul from despicable acts. It birthed the characteristics of work ethic in accordance to Islamic teachings, such includes optimism, Istiqamah, Wara', Ikhlas, Rida and Qana'ah. In addition, Ihsan attitude as a tarekat source has an impact on the behavior of entrepreneurs to always be honest and trustworthy in improving the quality of their economy.

Abstrak: Makalah ini mengkaji peran tarekat sebagai metode spritual dalam mendekatkan diri kepada Allah SWT dan perannya dalam membentuk etos kerja wirausahawan yang berlandaskan nilai-nilai tasawuf. Metode penelitian yang digunakan dalam penelitian ini adalah studi kepustakaan (library research). Studi ini bertujuan untuk menganalisis secara mendalam mengenai kontribusi dan peran ajaran tarekat terhadap etos kerja perilaku usaha/wirausaha penganut tarekat. Penelitian ini menemukan bahwa tarekat melalui metode zikir sebagai media pembersihan jiwa dari sifat-sifat tercela melahirkan karakteristik etos kerja yang yang sejalan dengan tuntunan ajaran Islam seperti sikap Optimisme, Istiqamah, Wara', Ikhlas, Ridha dan Qana'ah. Selain itu sikap Ihsan sebagai sumber tarekat berdampak kepada perilaku pelaku wirausaha untuk selalu bersikap jujur dan amanah dalam meningkatkan kualitas perekonomiannya.
\end{abstract}

Keywords: Tarekat, Sufism, Work Ethic, Entrepreneurship

\section{A. Introduction}

Islam as the perfect religion of Allah SWT gives guidance to people about halal business fields, ways of trying, and how humans must regulate working relationships with their fellow human beings in order to provide good benefits for the common good and can create prosperity and prosperity for all people. Islam does not only command humans to work for their own interests in lawful ways, but also commands human relations with others for the interests and benefits of human life in the universe. Therefore, in the field of business and entrepreneur- 
ship Islam really provides clear instructions, which can be used as guidelines for doing good business and entrepreneurship.

Islam is a complete way of life and entrepreneurship is part of the system ${ }^{1}$. Islam does not provide explicit explanations related to the concept of entrepreneurship, but between the two have a close enough relationship to have a spirit or soul that is very close even though the technical language used is different. It can be said that Islam itself does not directly promote entrepreneurial behavior. However, Islam, like all religions, teaches, promotes and spreads cultural values in the societies that are part of it ${ }^{2}$. Entrepreneurs are people who change the value of resources, labor, materials and other factors of production to be greater than before, and also people who make changes, innovations and new ways $^{3}$. In addition, an entrepreneur performs a managerial role in his activities, but routine management of ongoing operations is not classified as entrepreneurship. An individual may exhibit an entrepreneurial function when forming an organization, but subsequently performs managerial functions without carrying out their entrepreneurial functions. So, entrepreneurship can be temporary or conditional.

Talking about entrepreneurship is inseparable from the name of work ethic. The work ethic becomes an important discussion in relation to employers and the success of entrepreneurs in running their businesses ${ }^{4}$. Work ethic is a compound word consisting of two words with a unified meaning. The typical meaning is that the work ethic is a pragmatic concern. It shapes the individual and social behavior of the community. It can also mean the morale that characterizes a person's or group's beliefs. In general what is meant by work ethic is work morale which is based on certain values or norms. Work ethic can also be interpreted as a human attitude or view of the work done and which is based on the values that are believed. These values can come from a particular religion,

\footnotetext{
${ }^{1}$ Kamal Abdul Razak, Islamic Entrepreneurship Model, 2017.

2 Miles K. Davis, “Entrepreneurship: An Islamic Perspective," International Journal Entrepreneurship and Small Business 20, no. 67 (2013).

3 Bahri Bahri, "Kewirausahaan Islam: Penerapan Konsep Berwirausaha Dan Bertransaksi Syariah Dengan Metode Dimensi Vertikal (Hablumminallah) Dan Dimensi Horizontal (Hablumminannas)," Maro 1, no. 2 (2018): 67-86.

${ }^{4}$ Choirul Huda, "Etos Kerja Pengusaha Muslim (Studi Kasus Pada Pengusaha Muslim Alumni UIN Walisongo Semarang)," Economica: Jurnal Ekonomi Islam 7, no. 2 (2016): 79107.
} 
customs, culture, and certain laws and regulations that apply in a country. Religious and cultural values can encourage a person or group of people to achieve certain achievements, especially in the economic field ${ }^{5}$. Weber confirmed that. The influence of religious doctrine encourages a person to improve the quality of life, such as the quality of meeting economic needs. Religious motives that encourage the success of one's life can be found in the Islamic community in Indonesia. There is a huge similarity between the Protestant work ethic and the work ethic of the merchant santri. The terminology of the work ethic of the merchant santri illustrates the success of Muslim entrepreneurs in developing their businesses in several cities in Java in the 1950s, such as Yogyakarta, Surakarta, Pekalongan, Tegal, Ponorogo and other cities. This opinion was supported by Usman, who stated that the life history of Indonesian people showed a significant connection between the depth of religious appreciation and the excitement of economic life ${ }^{6}$. Certain groups that are classified as carrying out religious law more seriously, in social and personal life, seem more able to adapt to economic life.

In line with that Islam as a religion that emphasizes total submission to God both physically and mentally. This formalization of the total submission system is then packaged with a set of guidelines for outward practice (shari'ah) and ways or ways of purification of the heart (tarekat) ), who not only obey outward commands but also know God. In the midst of world noise, humans feel the longing for divine values, prophetic values, values that can lead humans back to nature. Religion motivates followers to improve work ethic and economic development into Sufism 7, because basically Sufism can strengthen the work ethic ${ }^{8}$, besides that individuals who follow moral principles in Islamic work ethics are expected to have collaborative work behavior in accordance with the

\footnotetext{
5 Max Weber, Etika Protestan Dan Semangat Kapitalisme (Terjemahan) (Pustaka Promethea, 2000).

6 Sunyoto Usman, "Perkembangan Dan Pemberdayaan Masyarakat," Yogyakarta: Penerbit Pustaka Pelajar, 1998.

7 M Amin Syukur and Abdul Muhaya, "Economic Movements Within Sufism in Java: A Case Study on Qadiriyah and Naqsyabandiyah Sufi Orders," Journal of Indonesian Islam 9, no. 2 (2015): 229-56, https://doi.org/10.15642/JIIS.2015.9.2.229-256.

8 Moh Saifullah, "Etos Kerja Pengikut Tarekat Qâdirîyah Wa Naqshabandîyah," Teosofi: Jurnal Tasawuf Dan Pemikiran Islam 2 (October 16, 2015): 264, https://doi.org/10.15642/teosofi.2012.2.2.264-291.
} 
teachings of the prophet Muhammad SAW ${ }^{9}$, similarly, muslim entrepreneurs must be involved in business ventures with pre-designed desires to engage in activities that please Allah SWT ${ }^{10}$, then it is not surprising that humans are interested in studying the tariqah (Sufism) and trying to practice it in everyday life, including in economic activities where there is an increasingly greater need to explore the role of centuries-old Sufism traditions and teachings which through social movements have contributed to, and continues to influence the development of human resources at various levels of individuals, groups, organizations, communities, nations, and internationally ${ }^{11}$. Running a business with a Sufistic or spiritual life pattern is the effort of the tarekat to practice religious teachings without withdrawing from worldly life. According to Nurcholish Madjid, the tarekat developing as it is today is the result of harmonizing between the tendency to " mysticism " and delicacy in a balanced way. Since the time of Imam Ghazali, there have been many attempts to harmonize the two trends by the ulama, so that the differences between the two need not be overly concerned ${ }^{12}$.

In Indonesia, many tarekat followers do not deny worldly life 13 , their activities in the political and economic fields, have been widely discussed and discussed since / colonial safe. According to Irwan Abdullah ${ }^{14}$, the santri business network, including followers of the tarekat, has been very strong in Java. They formed groups (business groups in several cities. Among them were Demak, Bawean, Kudus, Mojokuto, Batur Klaten, Karangkajen and Kotagede (Yogyakarta), Parakan (Temanggung), Kretek (Wonosobo), Pulosari and

${ }_{9}^{9}$ Muliati Usman and Norsiah Mat, "Islamic Work Ethic and Public Sector Innovation: Entrepreneurial Orientation as a Moderator," Jurnal Internasional Bisnis Dan Technopreneurship 7, no. 2 (2017): 205.

10 M Kabir Hassan and Will Hippler, "Entrepreneurship and Islam: An Overview," Available at SSRN 3263110, 2014.

11 Nadir N Budhwani and Gary N McLean, "The Roles of Sufi Teachings in Social Movements: An HRD Perspective," Advances in Developing Human Resources, 2019, 1523422319827938.

12 Nurcholish Majid, "Islam agama peradaban : membangun makna dan relevansi doktrin Islam dalam sejarah" (Jakarta: Paramadina, 1995), http://catalog.hathitrust.org/api/volumes/oclc/35743127.html.

13 Martin van Bruinessen, Tarekat Naqsyabandiyah Di Indonesia (Bandung: Mizan, 1996).

14 Irwan Abdullah, The Muslim Businessmen of Jatinom: Religious Reform and Economic Modernization in a Central Javanese Town (Universiteit van Amsterdam, 1994). 
Pekajangan (Pekalongan), Bumiayu (Brebes), Cilimus and Plered (Cirebon), and Sokaraja (Banyumas). In-depth research on this problem has been done by Labib ${ }^{15}$, Muhammad Sulthoni ${ }^{16}$, Cilfford Geertz in Mojokuto ${ }^{17}$, Castles in Kudus ${ }^{18}$ and de Jonge in Madura ${ }^{19}$. They revealed the importance of Islam's relationship with trade. Maybe now the attempt to re-explain the relationship between religion and trade is considered old-fashioned and boring, but in reality there is relevance between religion and economic activity that is constantly renewable. Social commodification brought by the market does not reduce the role of religion in society, instead it strengthens it.

One of the focus of interesting issues to be revealed is the influence of Islamic teachings instilled by the murshid (tarekat leaders) on his followers in carrying out economic activities, especially entrepreneurial behavior. This theme needs to be studied more broadly and deeply, bearing in mind the large number of members and leaders of the tarekat who are successful in running their business to the present day. In this study focuses on the role of the main teachings of the tarekat in general (not limited to the flow of certain tarekat) on the behavior of the entrepreneurial work ethic. The influence of the teachings of the tarekat on the behavior of entrepreneurs especially in running the business wheel is a novelty in this study. An in-depth study is needed to obtain a basic understanding of the relationship of the teachings of the tarekat with its impact on the behavior of the adherents of the tarekat.

15 Labib Muzaki Shobir, "Tasawuf Enterpreneurship: Membangun Etika Kewirausahaan Berbasis Prophetic Intelligence," An-Nisbah: Jurnal Ekonomi Syariah 3, no. 2 (2017): 417-32.

16 Muhammad Shulthoni and Dewi Puspitasari, "Bisnis Kaum Santri: Studi Tentang Kegiatan Bisnis Komunitas Tarekat Qadiriyah Naqsyabandiyah Pekalongan," Jurnal Penelitian 8, no. 1 (2012).

17 Clifford. Geertz, Aswab. Mahasin, and Bur. Rasuanto, “Abangan, santri, priyayi : dalam masyarakat Jawa” (Jakarta: Pustaka Jaya, 1983), http://books.google.com/books?id=7MTXAAAAMAAJ.

18 Geertz, Mahasin, and Rasuanto.

${ }^{19} \mathrm{H}$ de Jonge, Madura Dalam Empat Zaman: Pedagang, Perkembangan Ekonomi, Dan Islam : Suatu Studi Antropologi Ekonomi, Seri Terjemahan (Diterbitkan atas kerja sama Perwakilan Koninklijk Instituut voor Taal-, Land- en Volkenkunde (KITLV) dengan Lembaga Ilmu Pengetahuan Indonesia (LIPI) bersama penerbit PT. Gramedia, 1989), https://books.google.co.id/books?id=2YseAAAAMAAJ. 
This research is a library research ${ }^{20}$, where to obtain complete data on the tarekat and the work ethic of entrepreneurship which is then analyzed the role of the tarekat (Sufism) and its influence on the entrepreneurial work ethic. The data that has been collected is then analyzed by the analysis method, the synthesis method and the verstehen method. The method of analysis is a method which is used to describe the data that has been obtained and detailed one by one according to its parts. Synthesis method is a method used to combine data that has been obtained. In other words, overall the data that has been obtained are combined with one another so that a result can be obtained ${ }^{21}$. Finally, the results obtained are drawn conclusions by using the verstehen method or a method used to understand by drawing conclusions from the data that has been examined using logical rules that can be scientifically justified.

\section{B. Tarekat and Entrepreneurial Behavior}

Tarekat (arabic: حلرق tarîqah) means "path" or "method", and refers to the religious school of Sufism or Sufism in Islam ${ }^{22}$. It is conceptually related to haqîqah or "true truth", namely ideal ideals to be achieved by the perpetrators of the sect. A prosecutor of religious knowledge will begin his approach by studying Islamic law, that is, exoteric or worldly practices of Islam, and then proceed to the path of a mystical religious approach in the form of a tarekat. Through the spiritual practice and guidance of a tarekat leader, prospective followers of the tarekat will strive to achieve true nature or ultimate truth. Tarekat is the fruit of the shari'a. Sufism is fruit rather than tarekat. Sufism people must enter the tarekat, because in the tarekat there is a teacher or murshid or sheikh whose teacher pedigree continues from murshid to murshid until the Muhammad SAW and Allah Azza wa Jalla through the mediation of the angel Jibril as ${ }^{23}$. The purpose of joining the tarekat comes after the commitment to the Sufi way (Sufism) is taken by cleansing

20 James Danandjaja, “Metode Penelitian Kepustakaan,” Antropologi Indonesia, 2018, https://doi.org/10.7454/ai.v0i52.3318.

${ }^{21}$ Jane Noyes et al., "Chapter QQ: Qualitative and Implementation Evidence and Cochrane Reviews," Update, 2013.

${ }^{22}$ Ecep Ismail, “Landasan Qur'ani Tentang Zikir Dalam Ajaran Tarekat," Syifa Al-Qulub 1, no. 2 (2017): 195-201.

23 Syaifan Nur, "Tarekat Dan Jalan Menuju Bangsa Beradab," in Tarekat Dan Etika Kemandirian Diri, ed. Nunuk Rijojo Adi, Cetakan I (Yogyakarta: Muhyin Nufuus Media, 2013), 36. 
the heart ${ }^{24}$. Sufi leaders in the tarekat formulate how systematically, the ways, ways, and levels of the path that must be passed by prospective Sufis or tarekat students spiritually to be able to get closer to the presence of Allah SWT (taqarrub) ${ }^{25}$. Most tarekat teachers have taught a more or less the same approach, which is about dzikir on how to approach Allah ${ }^{26}$. One can only receive teaching (talqin) about these practices from an authorized teacher (mursyid), and only after declaring a promise of loyalty (bai'at) to the sheikh ${ }^{27}$. Someone who adheres to / follows a certain order is named salik (one who walks towards God) while the way they go according to certain ways is called suluk. Many things must be done by a salik if you want to get to the intended destination ${ }^{28}$. So it is quite clear that the tarekat is a system or method for taking the path that ultimately knows and feels the existence of God, where one can see his God with the eyes of his heart (ainul bashirah).

According to Al-Jurjani 'Ali bin Muhammad bin' Ali (740-816 M) ${ }^{29}$, tarekat is a special method used by salik (road walkers) towards Allah Taala through the stages / maqamat. Thus the tarekat has two meanings. First, it means the method of giving spiritual guidance to individuals in directing their lives towards closeness to God. Second, the tarekat as a brotherhood of Sufis is characterized by the existence of formal institutions such as zawiyah, ribath, or khanaqah. When viewed from the other side the tarekat has three systems, namely a system of secrecy, a kinship system (brotherhood), and a hierarchical system such as the caliph tawajjuh or caliphate of suluk, sheikh or murshid, saint or qutub. The position of the tarekat teacher is strengthened by the teachings of wasilah and

\footnotetext{
${ }^{24}$ Abdul Ghoffir Muhaimin, "Pesantren and Tarekat in the Modern Era: An Account of the Transmission of Traditional Islam in Java," Studia Islamika 4, no. 1 (1997).

25 Rahmawati Rahmawati, "Tarekat dan Perkembangannya," Al-Munzir 7, no. 1 (2014): 83-97.

26 Saliyo Saliyo, "Psychological Meaning of Spiritual Experience Participants Naqshbandiyah Khalidiyah in Kebumen Indonesia," QIJIS (Qudus International Journal of Islamic Studies) 6, no. 2 (2018): 309-38.

27 M Rohman Ziadi, "Tarekat dan Politik: Studi Living Sufism Tarekat Hizib Nahdlatul Wathan," Living Islam: Journal of Islamic Discourses 1, no. 2 (2018): 231-71.

28 Mansure Rahmani, Ahad Faramarz Gharamaleki, and Hassan Arif, "Journey in Sufism," Journal of Sufi Studies 7, no. 1-2 (2018): 125-39, https://doi.org/https://doi.org/10.1163/22105956-12341310. 1988).

${ }^{29}$ Al-Jurjani 'Ali bin Muhammad bin 'Ali, Al Ta'rifaat (Bairut: Dar al Kutub al Ilmiyah,
} 
genealogy. Successful belief with the teacher is strengthened by the belief in karamah, blessing or intercession or abundance of help from the teacher.

$$
\text { وأن لو استقاموا على الطريقة لأسقيناهم ماء غدقا }
$$

If they (the idolaters) tread the right path, We shall give them to drink of water in abundance (QS. Al-Jin: 72/16)

Based on this verse, the teachings of the tarekat are the teachings of the Islamic religion, not the teachings of the Salaf cleric (Ulama mid after the companions), as it is assumed by a small number of Muslims. The order is focused on the teachings of zikrullah, remembering Allah Almighty. The issue of zikrullah has been ridiculed or taught by the Prophet Muhammad Saw. In the Qor'an it says: "Verily in the messenger of Allah ye have a good example for him who looketh unto Allah and the Last Day, and remembereth Allah much.". (QS. Al-Ahzab: 33:21). Thus, it is clear that the path which is as close as possible to reach Allah swt, feels seen and cared for, can only be achieved by a servant with remembrance to Him, in addition to doing exercises (riyadah) physically and spiritually as is usually done by Sufis, between others are sincere, honest, zuhud, muraqabah, musyaadah, tajarrud, mahabbah, love for Allah and others, which are forms of zikrullah itself. The scholars of the tarekat / Sufism define it in the form of zikrullah amaliyah.

From the analysis of economics, through wara, zuhud, qonaah gratitude will create income distribution that fosters the real sector, then increases productivity and employment opportunities that will drive the economic pace ${ }^{30}$. Remembrance brings the essence of muraqabah. Muraqabah brings someone to the dignity of ihsan. With dignity ihsan a man can worship God as if seeing God, and this is the final degree of the Sufis. Muraqabah in a theoretical sense is similar to the introspective and vigilant attitude towards worship performed for Allah. This can be obtained through training. But on a practical level, muraqabah can only be obtained by the gift of God, for the guidance and blessings of the Murshid who constantly pray for his students to always be in the gift of Allah. In language, muraqabah means watching or waiting for something with full attention. In Sufism, this term means "the continual awareness of a servant of God's watch over

30 Mursal Mursal, Konsep Ekonomi Tasawuf (Telaah Kitab Al Luma', Al Hikam, Dan Risalatul Qusairiyah), Al-Qisthu: Jurnal Kajian Ilmu-Ilmu Hukum, vol. 14, 2016, https://doi.org/10.32694/010330. 
all his circumstances". Muraqabah is sitting contemplating or silence with sincerity, as if dealing directly with God, convinced yourself that Allah is always watching and watching. With muraqabah practice, a person will have a good value of Ihsan and will be able to feel the presence of God wherever and whenever he is.

Al-Qusyairi stated, "People who have not confirmed their fear of Allah and the introspective who are responsible for Him, will not reach kasyf (the opening of the veil between the servant and Allah) and syahadah (followers of Allah)." always pay attention to His servant. Allah says, "Verily, Allah always cares for all of you" (QS.An-Nisa': 4:1). See also QS. 33:52, QS. 13:33, QS. 96:14 and QS. 98:8. Rasulullah Saaw also said: "You should worship Allah as if you saw Him, and ifyou cannotsee Him, then He will seeyou." (HR. Muslim)

From these verses and traditions it can be concluded that muraqabah means the independence of a servant towards the Creator, the belief that $\mathrm{He}$ always supervises and pays attention to humanity, both their intentions and their deeds. Therefore, a servant must be introspective of the condition of the heart, intention, and charity that he works to carry out God's commands and leave His prohibitions. The teachings of Sufism that can be used as a guide in the problem of innovation is the doctrine of ihsan, which Sufistically means the feeling that oneself and all one's behavior is always supervised by God. The feeling of being watched by God creates a very strong motivation to always do something that benefits humans and the environment. Muraqabah is the origin of all goodness, happiness, and success. A servant will not arrive at muraqabah except after being able to introspect (muhasabah an-nafs). Muraqabah is a gift given by Allah to His servants who always worship Him, always perpetuate remembrance wherever he is, and constantly keep his heart from being littered with despicable qualities.

Furthermore, by practicing muraqabah through dhikr by the most engaged followers engaged in business activities, especially entrepreneurship, it gives an influence in which Allah always supervises and pays attention to him so that a Muslim entrepreneur will always maintain honesty and trust in seeking fortune. Honesty turns out to be a solid foundation for every business; honesty with oneself, with coworkers, both with business relations and with their own employees. Honesty in entrepreneurship is a principle that can not be bargained any longer, because from honesty, the exemplary (entrepreneurial) effort is first 
realized. And business cooperation (companies) will live long if there is honesty from all parties. Without honesty, business cooperation becomes very fragile 31 .

The word al-amanah, etymologically means "honest and straight". In terms of shar'i, it means "something that must be maintained and conveyed to those entitled to receive it". Thus honesty (al-amanah) here is a trait and attitude that is loyal, sincere, and honest in carrying out something entrusted to him, both in the form of property, secrets and duty obligations. Implementation of the mandate properly can be called "al-amin" which means that which can be trusted, honest, loyal, and safe. This obligation to have the nature of honesty is emphasized by Allah in the Qur'an:

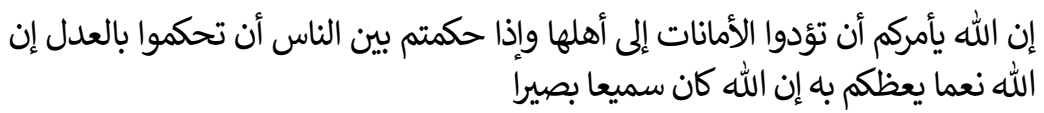

"Lo! Allah commandeth you thatye restore deposits to their owners, and, ifye judge between mankind, that ye judge justly. Lo! comely is this which Allah admonisheth you. Lo! Allah is ever Hearer, Seer" (QS. An-Nisa: 4:58).

If in general business activities must apply and consider ethical values or morality in them, then in more specific or small business activities, too. For example in the relationship between companies and employees. In relationships that bring forth obligations and rights, both parties must apply the ethical / moral dimension (trustworthiness and honesty / loyalty) ${ }^{32}$, because beforehand, the mandate in economic activity had not been much talked about, let alone practiced. According to religious instructions, the mandate must be fulfilled or more secure the achievement of its objectives with expertise, especially administrative expertise. In other words, the mandate can be delivered more effectively by applying the principles and functions of management or the trust is the most

\footnotetext{
31 Musa. Asyarie, "Islam, etos kerja \& pemberdayaan ekonomi umat” (Yogyakarta: Lesfi : $\quad$ Institut Logam, 1997), http://catalog.hathitrust.org/api/volumes/oclc/38937170.html.

32 For companies, unsafe behavior (betrayal) will cause loss and inefficiency, conflict with business partners, and loss of trust from consumers. If this continues, it is not impossible that the company will go bankrupt. see Ismail Yusanto, Menggagas Bisnis Islami / Muhammad Ismail Yusanto, Muhammad Karebet Widjajakusuma, ed. Muhammad Karebet Widjajakusuma (Jakarta: Gema Insani, 2002).
} 
appropriate value to be applied in relation to the formation of good management 33 .

\section{The Role of the Tarekat in Shaping the Islamic Entrepreneur Work Ethic}

In the results of Ema Yudiani's research ${ }^{34}$ there is a positive relationship between religiosity and the Islamic work ethic. The higher the religiosity, the higher the Islamic work ethic. The lower the religiosity, the lower the Islamic work ethic. To increase morale or work ethic in us, the main teachings of the tariqa that shape the personality of Ihsan, then the person imagines that indeed Allah sees his actions) ${ }^{35}$. The teachings of the tarekat include, optimism, Istiqamah, Patient, Ikhlas, Ridha, Qana'ah, Takwa, Fear, Tawakal, Penance, Zuhud, Wara ', Gratitude, Love, Longing, Shidiq, Syaja'ah, Takdir, Destiny, Fate, Embarrassment, Recitation, Prayer, Tafakkur, Uzlah, Poverty, and Death ${ }^{36}$. Some of the teachings of the tarekat that will be discussed include the attitude of optimism, istiqamah, wara ', sincerity, ridha and qana'ah, where these attitudes have the most significant impact on the work ethic of an entrepreneur described as follows:

The attitude of optimism or hope clearly has a purpose that can make a person's work spirit become strong, because to create this attitude of optimism requires a great effort as well. If his hope is to meet with God, then he must try hard to get closer to him. But if he hopes his world life is better, then he must work hard and be serious. For this reason, Sufism can invite us to work hard to achieve what we want, but if that hope is not achieved then we must not despair, because this is very contrary to the attitude of optimism.

Next is Istiqamah attitude or firm attitude towards something, Istiqamah is one of the important things in doing a job. With a firm or consistent attitude that we have, then we will easily get what we want. Consistent here we can see from

33 M D Rahardjo, Etika Ekonomi Dan Manajemen (Tiara Wacana Yogya, 1990), https://books.google.co.id/books?id=oZ4OAAAAIAAJ.

34 Ema Yudiani, "Etos Kerja Islami Dosen Fakultas Ushuluddin dan Pemikiran Islam UIN Raden Fatah Palembang Ditinjau Dari Religiusitas," Jurnal Psikologi Islam, 2016.

35 Farikoh Farikoh and Miftahun Ni'mah Suseno, "Analisis Pengaruh Kepribadian Ihsan Terhadap Kecendurungan Akademik Pada Mahasiswa Program Pedidikan UIN Sunan Kalijaga Yogyakarta," Psikologika: Jurnal Pemikiran Dan Penelitian Psikologi, 2017, https://doi.org/10.20885/psikologika.vol20.iss2.art5.

36 Sudirman Tebba, Bekerja Dengan Hati : Bagaimana Membangun Etos Kerja Dengan Spiritualitas Religius (Jakarta: Bee Media Indonesia, 2006). 
various aspects, especially in terms of the behavior that we will do. Someone who has no consistency then he will always fail in doing his work. Istiqamah in question is related to good deeds, and does not harm or even violate religious rules.

Ikhlas attitude is the basis of the most ideal work ethic, because with sincere attitude a person will never know tired in carrying out his work. Unlike someone who does not have a sincere attitude, he will harm many parties, especially himself. Sincere attitude also makes someone do honest in his work. Thus, a person will be responsible for the work he does, he also realizes that the work he does not only benefit himself, but also for others; Ridha means being happy, it is also a necessary attitude in increasing morale. Ridho here means being happy with all the commands of God, including the command to make a living. That means we as Muslims must try hard to face life. Making a living is one of the actions.

Next is the attitude of Qana'ah, which is the attitude of feeling sufficient with what has been obtained. The purpose of qana'ah teaches us to be satisfied with what we have, because we are not motivated by actions that are hated by Allah, such as corruption or stealing. The attitude of qana'ah is also intended so that people do not look for haram money just because their legal work does not generate as much money as needed. Then the attitude of the Tawakal, which is the attitude of surrender to God, for what we have done. Whatever result God gives, we must be firm in accepting it. Efforts made continuously are also one of the moral actions that are fostered by the attitude of trust. Repentance contains a high work ethic, because basically repentance is to repair oneself from reprehensible actions back to commendable deeds as has been taught by Islam, namely by finding and returning illicit wealth that has been obtained. So repentance can improve our morals to make a living halal and return it back with halal sustenance. Zuhud is one of the attitudes taught by Sufism, which is to remind humanity not to love too much wealth in this world.

Wara 'also includes one of the attitudes taught in Sufism, wara' means abstaining. That is, we must leave things that are not useful or unlawful. Wara 'also aims to control our desires for wealth in this world. To prosper our lives, with the attitude of wara 'we will not do acts that are forbidden by religion. With gratitude we can also increase morale, meaning that we can thank Allah SWT, for the favors we get, thanking is not only done verbally, it must also be followed by action. For example, by working harder. Work here in order to obey God, so that the work 
must not be tarnished in the least by acts that are forbidden by God. Love is the most important thing in increasing morale.

The role of the tarekat which is emphasized on the Dhikr amaliyah along with other mandatory practices can bring personal entrepreneurs who have a perfect work ethic. By saying the name of Allah or Wirid, doing sunnah prayers, reading the Qur'an, $d z i k r$, and prayers, in addition to getting the reward for those who do it, can also make a person's peace of mind and mind. So it is very important to increase morale. Without that calm, we will not feel calm, even can cause our work to be destroyed or not optimal. Like wirid, by multiplying remembrance people will always remember Allah and His commands, such as working and earning a living for the family. Thus remembrance can also increase a strong morale. Remembrance can also provide peace of mind and mind, so that people today who are experiencing a lot of stress and can disturb their souls and minds, by multiplying $d z i k r$ people who feel stressed can feel calmer in doing their work.

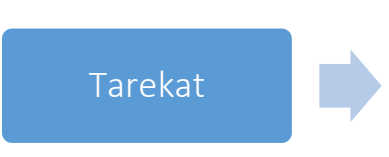

Dzikir Amaliyah

(Mursyid Guidance)
Tasawuf

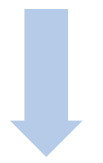

Entrepreneurial Work Ethic

Ikhlas

Ridha

Qana'ah

Source: Own Writer

Figure I: The Tarekat Process in Forming Work Ethics of Entrepreneurs

Figure 1 above shows the process of the tarekat method in shaping the attitudes and behaviors of an entrepreneurial work ethic, beginning with the 
entry of a person into a certain tarekat through the bai'at process by the murshid as the leader of the tarekat who then gets a particular dzikir. In this spiritual journey (suluk) a student (salik) is required to apply the teachings of Sufism through guidance from his murshid. The ongoing process of riyadhoh mujahadah (habituation) will gradually form a moral personality which then gives birth to a work ethic in entrepreneurship based on Sufism principles such as optimism, istiqomah, Wara', Ikhlas, ridha and qana'ah.

\section{An Honest and Trustworthy Work Ethic: Ihsan implications as a source of tarekat}

From the analysis of experience in the field, the basic characteristics of entrepreneurship for success can be summarized in three attitudes ${ }^{37}$ : Honest, Having a long-term goal, in the sense of having a clear picture of the final development of the business carried out and Always be obedient to pray, which is surrender to God to ask for what is desired and accept whatever results are obtained.

When a business person can be honest, he has actually invested the largest share capital in doing business. He will get various conveniences in his life. There have been many stories of people succeeding in their business, because they only have honesty capital. Rasulullah Saaw is one example. In business he always acts honest, does not reduce the scales, does not hide damaged goods and does not set a high price. So history also records the Prophet as one of the people who succeeded in his business with only capital of honesty. On another occasion the Messenger of Allah affirmed: "Be honest, because honesty actually leads to goodness, and in fact honesty leads to heaven. And stay away from lies, because they lead to sin and evil, and in fact they lead to hell. "(Bukhari). The life attitude of people who have an Islamic work ethic will reflect their aqidah including upholding the values of honesty in carrying out their activities ${ }^{38}$, because he has the belief that God is the Almighty thatsees everything and wherever the activities of his servants do.

37 Aprijon Aprijon, “Kewirausahaan Dan Pandangan Islam," Menara 12, no. 1 (2013):

38 Didi Sunardi, "Etos Kerja Islami," JISI: Jurnal Integrasi Sistem Industri 1, no. 1 (2014): 85 . 


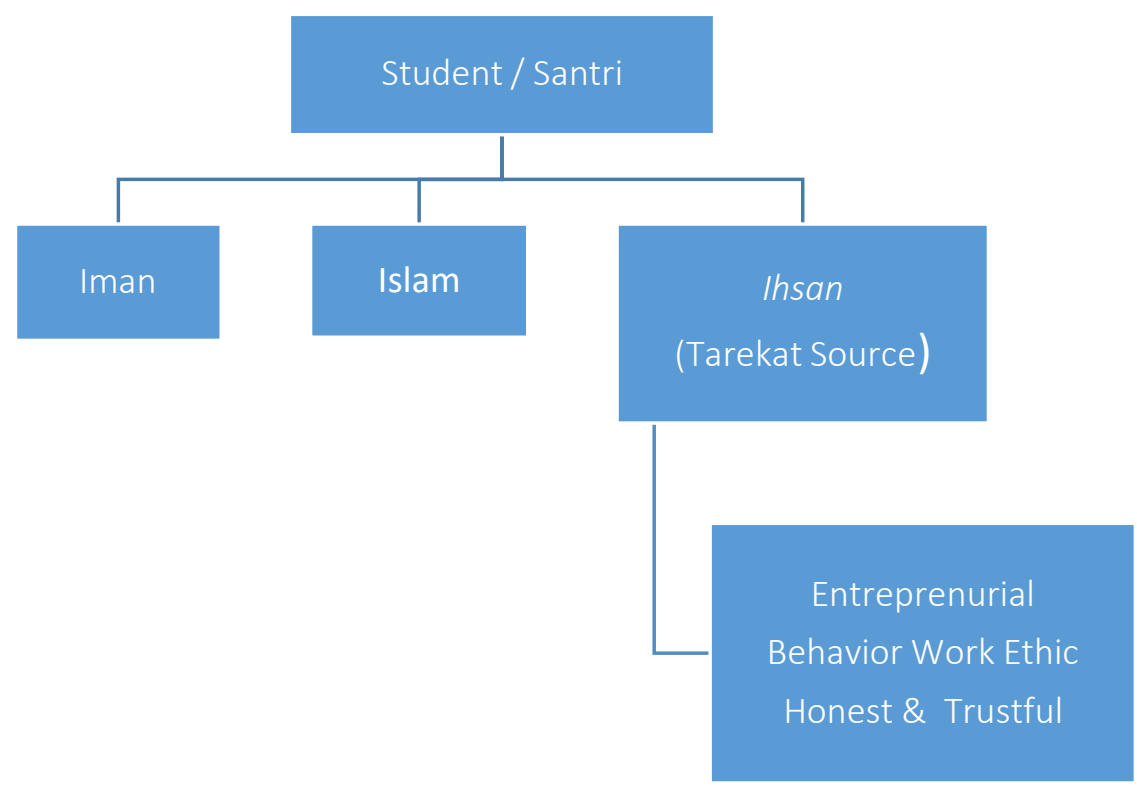

Source: Own Writer

Figure 2: Ihsan (Source of the Order) \& Its Implications on Business Conduct and Work Ethics

Figure 2 above shows that ihsan which is the source of the tarekat can realize an honest and trustworthy work ethic and entrepreneurial behavior. In the quality of the work ethic of appreciation of a charity that is "Ihsan" more is the First; do the best or better, as for the message it contains is that every Muslim has a commitment to himself to do the best in everything he does. Both of these means "better" than the performance or quality of previous work. The second work ethic that is born of ihsan is trustful. In Arabic, the word amanah is taken from the roots of the words alif, mim and nun which have two meanings: 1) the opposite of the word betrayal namely calmness and peace of heart, 2) al-tasdiq namely justification ${ }^{39}$. Trust can be interpreted as establishing promises and deposits. Amanah means trusted, rooted in the word faith. The nature of the mandate is born from the power of faith, the thinner the faith of a person fades also the nature

${ }^{39}$ Abu al-Husain Ahmad bin Faris bin Zakariya, "Mu"jam Maqa Yi s Al-Lugah" (Beirut: Dar al-Fikr, 1994), 169. 
of the mandate in him ${ }^{40}$. Between the two there is a very close connection, Rasulullah SAW said: "The imperfect faith of someone who is not trustworthy, and imperfect religion of people who do not keep promises". (HR. Ahmad). Thus, the trust that comes from God Almighty. related to all forms of commands and prohibitions imposed on humans. While the mandate of humans is related to all forms of trust, both in the form of property, position and secret 41. As good as someone's profession is an entrepreneur or trader by always maintaining the mandate, not lying, not condemning, and others. Traders with Islamic work ethics in work sourced from Islamic beliefs or akidah based on the Qur'an and Hadits will provide great motivation to each of them to be always eager to work and can improve business performance in trading. Work morals can apply to the corridors of religious norms. ${ }^{42}$, in this case the Islamic values that can be used as a reference for this study is an exemplary act that is found in the characteristics of the Prophet Muhammad SAW which is the nature of șiddiq and trustworthy. From the characteristics of the Prophet Muhammad saw his behavior as a reference model for humanity.

\section{E. Conclusion}

The values and teachings followed by the followers of the tarekat can have an influence on economic activities, especially in entrepreneurship. The followers are attached through guidance given by the murshid and training themselves with dzikir as a medium to cleanse the soul of the despicable traits which then impact the entrepreneur to always be honest and trustworthy in improving the quality of his economy through business and trade activities. Dzikir Amaliya tarekat through the guidance of murshid (tarekat leader) in a continuous and systematic way can form a work ethic pattern for Muslim entrepreneurs and certain tarekat groups which subsequently becomes a reference and guide in economic behavior based on the principles of Sufism. In addition, Ihsan as a source of tarekat becomes a

40 Zainal Abidin and Fiddian Khairudin, "Penafsiran Ayat-Ayat Amanah Dalam AlQur'an," Syahadah 5, no. 2 (2018).

41 Buhari, "Nilai - Nilai Pendidikan Amanah Dalam Al-Qur'an," Jurnal Madania 4 (2014): 146.

42 Fatmawati Fatmawati, "Fungsi Tasawuf Terhadap Pembentukan Akhlak (Etika) Kerja: Studi Pada Murid Tarekat Qadiriyah Naqsyabandiyah Di Kota Pontianak Kalimantan Barat," Jurnal Theologia 24, no. 2 (2013): 115-38. 
shaper of the character of an honest and trustworthy entrepreneur who is a trait of the Prophet Muhammad who is a role model in all aspects.

\section{BIBLIOGRAPHY}

Abdul Razak, Kamal. Islamic Entrepreneurship Model, 2017.

Abdullah, Irwan. The Muslim Businessmen of Jatinom: Religious Reform and Economic Modernization in a Central Javanese Town. Universiteit van Amsterdam, 1994.

Abidin, Zainal, and Fiddian Khairudin. "Penafsiran Ayat-Ayat Amanah Dalam AlQur'an." Syahadah 5, no. 2 (2018).

Abu al-Husain Ahmad bin Faris bin Zakariya. “Mu“jam Maqa Yi s Al-Lugah,” 169. Beirut: Dar al-Fikr, 1994.

Al-Jurjani ‘Ali bin Muhammad bin 'Ali. Al Ta'rifaat. Bairut: Dar al Kutub al Ilmiyah, 1988.

Aprijon, Aprijon. "Kewirausahaan Dan Pandangan Islam." Menara 12, no. 1 (2013): 1-11.

Asyarie, Musa. "Islam, etos kerja \& pemberdayaan ekonomi umat." Yogyakarta: Lesfi: Institut Logam, 1997. http://catalog.hathitrust.org/api/volumes/oclc/38937170.html.

Bahri, Bahri. "Kewirausahaan Islam: Penerapan Konsep Berwirausaha Dan Bertransaksi Syariah Dengan Metode Dimensi Vertikal (Hablumminallah) Dan Dimensi Horizontal (Hablumminannas)." Maro 1, no. 2 (2018): 67-86.

Budhwani, Nadir N, and Gary N McLean. "The Roles of Sufi Teachings in Social Movements: An HRD Perspective." Advances in Developing Human Resources, 2019, 1523422319827938.

Buhari. "Nilai - Nilai Pendidikan Amanah Dalam Al-Qur'an." Jurnal Madania 4 (2014): 146.

Danandjaja, James. "Metode Penelitian Kepustakaan." Antropologi Indonesia, 2018. https://doi.org/10.7454/ai.v0i52.3318.

Farikoh, Farikoh, and Miftahun Ni'mah Suseno. "Analisis Pengaruh Kepribadian 
Ihsan Terhadap Kecendurungan Akademik Pada Mahasiswa Program Pendidikan UIN Sunan Kalijaga Yogyakarta." Psikologika: Jurnal Pemikiran Dan Penelitian Psikologi, 2017. https://doi.org/10.20885/ psikologika.vol20.iss2.art5.

Fatmawati, Fatmawati. “Fungsi Tasawuf Terhadap Pembentukan Akhlak (Etika) Kerja: Studi Pada Murid Tarekat Qadiriyah Naqsyabandiyah Di Kota Pontianak Kalimantan Barat." Jurnal Theologia 24, no. 2 (2013): 115-38.

Geertz, Clifford., Aswab. Mahasin, and Bur. Rasuanto. "Abangan, santri, priyayi : dalam masyarakat Jawa." Jakarta: Pustaka Jaya, 1983. http://books.google.com/books?id=7MTXAAAAMAAJ.

Hassan, M Kabir, and Will Hippler. "Entrepreneurship and Islam: An Overview." Available at SSRN 3263110, 2014.

Huda, Choirul. "Etos Kerja Pengusaha Muslim (Studi Kasus Pada Pengusaha Muslim Alumni UIN Walisongo Semarang)." Economica: Jurnal Ekonomi Islam 7, no. 2 (2016): 79-107.

Ismail, Ecep. "Landasan Qur'ani Tentang Zikir Dalam Ajaran Tarekat." Syifa AlQulub 1, no. 2 (2017): 195-201.

Jonge, H de. Madura Dalam Empat Zaman: Pedagang, Perkembangan Ekonomi, Dan Islam: Suatu Studi Antropologi Ekonomi. Seri Terjemahan. Diterbitkan atas kerja sama Perwakilan Koninklijk Instituut voor Taal-, Land- en Volkenkunde (KITLV) dengan Lembaga Ilmu Pengetahuan Indonesia (LIPI) bersama penerbit PT. Gramedia, 1989. https://books. google.co.id/books?id=2YseAAAAMAAJ.

Majid, Nurcholish. "Islam agama peradaban : membangun makna dan relevansi doktrin Islam dalam sejarah." Jakarta: Paramadina, 1995. http://catalog.hathitrust.org/api/volumes/oclc/35743127.html.

Martin van Bruinessen. Tarekat Naqsyabandiyah Di Indonesia. Bandung: Mizan, 1996.

Max Weber. Etika Protestan Dan Semangat Kapitalisme (Terjemahan). Pustaka Promethea, 2000.

Miles K. Davis. “Entrepreneurship: An Islamic Perspective." International Journal 
Entrepreneurship and Small Business 20, no. 67 (2013).

Muhaimin, Abdul Ghoffir. "Pesantren and Tarekat in the Modern Era: An Account of the Transmission of Traditional Islam in Java." Studia Islamika 4, no. 1 (1997).

Mursal, Mursal. Konsep Ekonomi Tasawuf (Telaah Kitab Al Luma', Al Hikam, Dan Risalatul Qusairiyah). Al-Qisthu: Jurnal Kajian Ilmu-Ilmu Hukum. Vol. 14, 2016. https://doi.org/10.32694/010330.

Noyes, Jane, Karin Hannes, Andrew Booth, Janet Harris, Angela Harden, Jennie Popay, and T Pantoja. "Chapter QQ: Qualitative and Implementation Evidence and Cochrane Reviews.” Update, 2013.

Nur, Syaifan. “Tarekat Dan Jalan Menuju Bangsa Beradab.” In Tarekat Dan Etika Kemandirian Diri, edited by Nunuk Rijojo Adi, Cetakan I., 36. Yogyakarta: Muhyin Nufuus Media, 2013.

Rahardjo, M D. Etika Ekonomi Dan Manajemen. Tiara Wacana Yogya, 1990. https://books.google.co.id/books?id=oZ40AAAAIAAJ.

Rahmani, Mansure, Ahad Faramarz Gharamaleki, and Hassan Arif. "Journey in Sufism." Journal of Sufi Studies 7, no. 1-2 (2018): 125-39. https://doi.org/https://doi.org/10.1163/22105956-12341310.

Rahmawati, Rahmawati. "Tarekat dan Perkembangannya." Al-Munzir 7, no. 1 (2014): 83-97.

Saifullah, Moh. "Etos Kerja Pengikut Tarekat Qâdirîyah Wa Naqshabandîyah." Teosofi: Jurnal Tasawuf Dan Pemikiran Islam 2 (October 16, 2015): 264. https://doi.org/10.15642/teosofi.2012.2.2.264-291.

Saliyo, Saliyo. "Psychological Meaning of Spiritual Experience Participants Naqshbandiyah Khalidiyah in Kebumen Indonesia." QIJIS (Qudus International Journal of Islamic Studies) 6, no. 2 (2018): 309-38.

Shobir, Labib Muzaki. "Tasawuf Enterpreneurship: Membangun Etika Kewirausahaan Berbasis Prophetic Intelligence." An-Nisbah: Jurnal Ekonomi Syariah 3, no. 2 (2017): 417-32.

Shulthoni, Muhammad, and Dewi Puspitasari. "Bisnis Kaum Santri: Studi Tentang Kegiatan Bisnis Komunitas Tarekat Qadiriyah Naqsyabandiyah 
Pekalongan." Jurnal Penelitian 8, no. 1 (2012).

Sudirman Tebba. Bekerja Dengan Hati: Bagaimana Membangun Etos Kerja Dengan Spiritualitas Religius. Jakarta: Bee Media Indonesia, 2006.

Sunardi, Didi. "Etos Kerja Islami." JISI: Jurnal Integrasi Sistem Industri 1, no. 1 (2014): 85.

Syukur, M Amin, and Abdul Muhaya. "Economic Movements Within Sufism in Java: A Case Study on Qadiriyah and Naqsyabandiyah Sufi Orders." Journal of Indonesian Islam 9, no. 2 (2015): 229-56. https://doi.org/10.15642/JIIS.2015.9.2.229-256.

Usman, Muliati, and Norsiah Mat. "Islamic Work Ethic and Public Sector Innovation: Entrepreneurial Orientation as a Moderator." Jurnal Internasional Bisnis Dan Technopreneurship 7, no. 2 (2017): 205.

Usman, Sunyoto. “Perkembangan Dan Pemberdayaan Masyarakat.” Yogyakarta: Penerbit Pustaka Pelajar, 1998.

Yudiani, Ema. "Etos Kerja Islami Dosen Fakultas Ushuluddin dan Pemikiran Islam UIN Raden Fatah Palembang Ditinjau Dari Religiusitas." Jurnal Psikologi Islam, 2016.

Yusanto, Ismail. Menggagas Bisnis Islami / Muhammad Ismail Yusanto, Muhammad Karebet Widjajakusuma. Edited by Muhammad Karebet Widjajakusuma. Jakarta: Gema Insani, 2002.

Ziadi, M Rohman. "Tarekat dan Politik: Studi Living Sufism Tarekat Hizib Nahdlatul Wathan." Living Islam: Journal of Islamic Discourses 1, no. 2 (2018): 231-71. 